\title{
Perancangan Sistem Monitoring Parameter Kualitas Udara (Suhu, CO, LPG dan Debu) berbasis IOT
}

\section{Design of Air Quality Parameter Monitoring System (Temperature, CO, LPG and Dust) based on IOT}

\author{
Jacson Victor Morin dan Darma Santi* \\ Jurusan Kimia FMIPA Universitas Papua \\ Jl. Gunung Salju Amban, Manokwari; Kode Pos: 98214 \\ *Email: d.santi@unipa.ac.id
}

\begin{abstract}
Research has been carried out on the design of a monitoring system for air quality parameters (temperature, CO, LPG and dust) whose data is integrated in real time. The measuring instrument uses the Arduino Uno R3 microcontroller base. The MQ-9 and MQ-5 gas sensors are used to measure air pollution, while the LM35 and DSM 501A sensors are used for temperature and dust. This system is also connected with Xbee S2 as a data sender and receiver based on WIFI. The voltage source is connected to a $10 \mathrm{~W}$ solar panel which is regulated by the charger controller so that when the battery is full, the battery charging connection will be disconnected. The software used is Arduino IDE 1.8.1 and X-CTU. The data that can be measured by the tool is the level of air pollution of CO and LPG gas, air temperature and PM 2.5 particulates in the air. The measurement phase was tested with samples of gas (CO and LPG) as well as a heat source and a cold source for temperature. The test data shows that all sensors are able to detect the presence of $\mathrm{CO}$ and LPG gas, temperature differences and dust levels in the air and then display the data in real time.
\end{abstract}

Keywords: Arduino Uno R3, Xbee S2, MQ-9, MQ-5, LM35, DSM 501A

\section{PENDAHULUAN}

Udara merupakan komponen komponen lingkungan yang sangat penting dalam kehidupan dan perlu dipelihara kualitasnya. Kondisi kualitas udara dewasa ini semakin menampakkan kondisi yang sangat memprihatinkan. Sumber polusi udara dapat berasal dari berbagai kegiatan antara lain industri, transportasi, perkantoran dan perumahan. Berbagai kegiatan tersebut merupakan kontribusi terbesar bagi polusi udara yang secara sengaja maupun tidak sengaja dibuang ke lingkungan sekitar (Departemen Kesehatan, 2015). Pencemaran terjadi ketika kemampuan udara telah terlampaui untuk menerima zat-zat lain (Fardiaz, 2008).
Penentuan suatu wilayah akan kualitas udaranya merupakan hal yang tidak mudah dilakukan, dikarenakan biaya operasional pemantauan serta biaya analisis parameter kualitas udara yang tidak murah harganya. Data yang akurat serta real time juga merupakan faktor yang yang menjadi kendala dalam menentukan baik atau buruknya kualitas udara suatu wilayah. Salah satu solusi yang penulis ajukan yakni melakukan pemantauan kualitas udara secara real time dan up to date menggunakan sitem pengukuran otomatis. Sebagaimana telah banyak diterapkan dalam berbagai aplikasi, sistem sensor dan telemetri memungkinkan informasi yang diperoleh sensor dari lokasi yang jauh (remote), diketahui secara langsung (real time) dan kontinyu dari lokasi yang lain. Ditambah 
dengan kemampuan data logger dalam menyimpan data untuk kurun waktu yang lama. Parameter yang dapat diukur secara langsung yaitu untuk parameter kualitas udara yaitu Suhu, kebisingan, CO, LPG serta Debu. Data implementasi dari sistem monitoring ini dikirim via Wifi melalui modul Xbee pengirim (Transmitter) ke modul Xbee penerima (Receiver), (Putu, 2015). Berdasarkan latar belakang tersebut maka penulis mendesain sistem monitoring untuk parameter kualitas udara (suhu, CO, LPG dan debu) berbasis Arduino Uno.

\section{METODE PENELITIAN}

\subsection{Rancangan penelitian}

Pada penelitian ini Sistem pemantau lingkungan perairan dan udara yang dikembangkan menggunakan rancangan umum dari sistem yang dikembangkan. Pembuatan bagian bagian sistem monitoring ini dapat dilihat pada pembagian berikut:

\subsubsection{Sistem sensor dan akuisisi data}

Sensor adalah device yang berfungsi untuk mengubah besaranbesaran fisik yang ada di alam menjadi besaran listrik sehingga mampu diolah secara elektronika. Besaran yang diukur pada sistem monitoring ini yang dibangun terdiri atas pengukuran parameter air yaitu Suhu, Carbon Monoksida (CO), Liquified Petroleum Gas (LPG) dan Debu

Keluaran dari sensor pada umumnya memiliki perubahan yang kecil dan cenderung tidak stabil sehingga membutuhkan rangkaian penyangga (buffer) yang berfungsi untuk menstabilkan perubahan keluaran sekaligus memperkuat sinyal perubahan sensor. Keluaran dari sistem sensor ini kemudian diumpankan ke sistem ADC (Analog to Digital Converter) untuk merubah sinyal analog sensor menjadi sinyal-sinyal dalam bentuk digital yang nantinya akan diolah oleh mikrokontroler. ADC yang digunakan dalam sistem ini merupakan fitur built-in dari mikrokontroler yang digunakan. Adapun karakteristik ADC yang digunakan yaitu: Presisi 10 bit (1024 kemungkinan keluaran), Tegangan kerja 0 - 5 Volt, Frekuensi cacah $12.500 \mathrm{KHz}$, dan Tipe pencacahan Successive Approximation.

Mikrokontroler yang digunakan adalah tipe ATMega328. Ada tiga fungsi utama mikrokontroler dalam sistem yang dibangun yaitu: (1) Sebagai ADC yang merupakan fitur built-in dari mikrokontroler ini, (2) Sebagai pegolah sinyal yang telah dibaca oleh ADC, menyusun data tersebut menjadi format data dan mengatur pewaktuan serta sinkronisasi pengiriman data ke sistem pengirim (transmiter), dan (3) Mengirimkan data, menerima respon dari dan ke sistem pengirim melaui Xbee S2.

\subsubsection{Komunikasi sensor, xbee $s 2$ dan arduino}

Blok diagram aplikasi ArduinoUno menggunakan masukan Xbee dan keluaran serial dapat dilihat pada gambar dibawah ini :

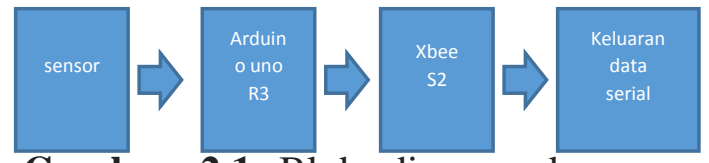

Gambar 2.1 Blok diagram komponen utama

\subsubsection{Melakukan setting xbee}

Sebelum menggunakan XBee terlebih dahulu harus dikonfigurasi. beberapa langkah yang dilakukan agar XBee pada Pemancar dan XBee pada penerima dapat saling bertukar data.

- Dihubungkan Xbee S2 ke PC/laptop dengan menggunakan Xbee adapter. Xbee harus dihubungkan secara serial dengan PC/laptop.

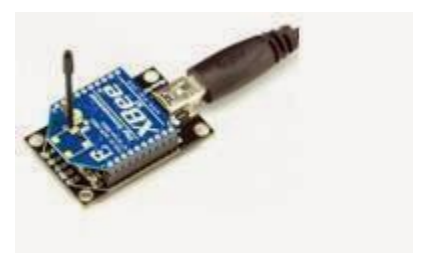


Gambar 2.2 Xbee adapter

- Open software XCTU pada komputer, jika modul RF berhasil terdeteksi software akan terlihat seperti pada gambar dibawah. "Port USB-to-serial Bridge..[COM1]" menandakan bahwa modul menggunakan saluran port USB COM1. Jika belum terdeteksi maka dicek status port USB komputer di Device Manager.

- Jika koneksi antara X-CTU dengan XBee gagal, maka akan muncul sebuah pesan kesalahan dan jika koneksi berhasil, maka akan tampil modem type dan firmware version dari XBee yang sedang digunakan.

- Mengatur Baud Rate, Flow Control, Data Bits, Parity, Stop Bits seperti pada kotak merah (gambar atas). Kemudian klik "Test/Query", maka identitas atau versi X-Bee akan muncul

- Kemudian, dipilih menu "Modem Configuration", kemudian diklik "Read" untuk mensetting nilai parameter dari X-Bee S2. Setelah diread maka akan muncul parameterparameter yang dapat disetting. Tipe dan versifirmware X-Bee yang terdeteksi juga akan sama seperti pada Com Test. Dipastikan bahwa Tipe dan Versi tidak diubah ke yang lain. Begitu juga dengan "Function Set.

- Untuk komunikasi point to point, umumnya hanya ada 3 parameter yang wajib di-setting yaitu PAN ID (Personal Area Network ID), DL (Destination Address Low), MY (16bit Source Address). $\mathrm{XBee}_{1}$ dan $\mathrm{XBee}_{2}$ dapat saling berkomunikasi.

- Dielakukan komunikasi lakukan pengaturan pada beberapa parameter berikut ini :

Nilai parameter DL X-Bee ${ }_{1}=$ MY XBee.
Nilai parameter MY X-Bee $1=$ DL X$\mathrm{Bee}_{2}$

$\mathrm{X}-\mathrm{Bee}_{1}$ dan $\mathrm{X}-\mathrm{Bee}_{2}$ menggunakan alamat PAN ID yang sama

Nilai parameter yang diisi berupa bilangan hexadecimal.

- Setelah itu dilakukan konfigurasi beberapa parameter, langkah terakhir yaitu menyimpan konfigurasi yang telah dilakukan pada XBee. Untuk menyimpan konfigurasi tersebut, cukup dengan menekan tombol "Write" pada X-CTU. Di bawah ini gambar hasil read dan writeXBee.

\subsubsection{Mekanisme kerja sistem}

- Input : Modul Xbee Penerima (Xbee Rx)

Output : Serial ( Komputer)

- Xbee Penerima akan menerima data yang dipancarkan dari Xbee Pemancar. Data dari pin Xbee Penerima dihubungkan ke pin $\mathrm{Rx}$ Arduino. Pin VCC pada modul Xbee Penerima dihubungkan ke $3.3 \mathrm{~V}$ Arduino dan Pin GND pada modul Xbee Penerima dihubungkan ke GND Arduino.

- Data yang diterima oleh Modul Xbee Penerima, akan di proses oleh Arduino. Arduino akan memproses data dari Modul Xbee Penerima untuk kemudian dikeluarkan dalam bentuk Serial (Komputer).

\subsection{Alat dan bahan}

Penelitian ini menggunakan

hardware dan software dalam mendeteksi serta komunikasi antara pengirim dan penerima (RX-TX). Beberapa peralatan dan bahan dirincikan sebagai berikut:

\subsubsection{Alat}

Pipa paralon 1 inch $(4 \mathrm{~m})$, sambungan pipa letter $\mathrm{T}(6 \mathrm{bh})$, sambungan pipa letter L (4 bh), Lem PVC, lem tembak 


\subsubsection{Peralatan (hardware dan Software)}

Arduino uno R3 (5 unit), Xbee S2 (5 unit), Shield Xbee S2 (5 unit), Colar Cell 10 W output 12 Volt (1 unit), Controller Charger 12 Volt (1 unit), Acuu output 12 Volt 5 Ah (1 unit), Sensor LM35 (1 unit), Sensor DSM501A (1 unit), Sensor MQ-9 (1 unit), Sensor MQ5 (1 unit), Kabel jumper Male to Famale (12 buah), kabel jumper Male to Male (11 buah), kabel konektor USB arduino (2 bh), Software Arduino Uno R3 dan Software XCTU, Laptop Hp (1 unit) dan kamera nikon D90 (1 unit)

\subsubsection{Perangkat lunak alat diagram alir program}

Diagram alir program aplikasi ArduinoUno menggunakan masukan sensor Suhu, Carbon Monoksida, LPG, Debu dan Kebisingan dengan luaranXBee dapat dilihat pada Gambar 4.2 :

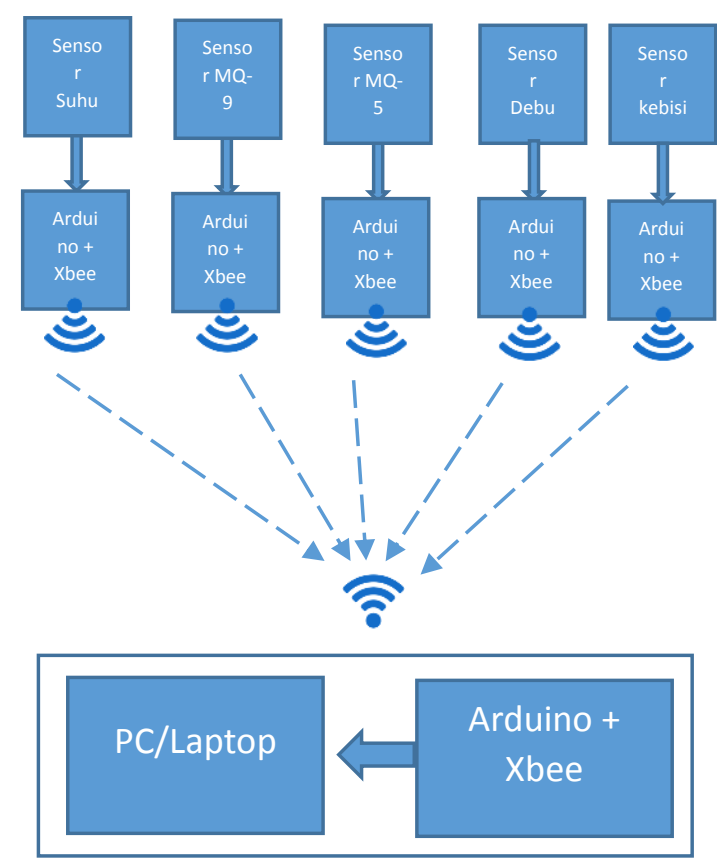

Gambar 2.3 Diagram alir program
Berdasarkan metode kerja rangkaian alat system monitoring kualitas udara, maka akan terlihat seperti pada Gambar 3.1.

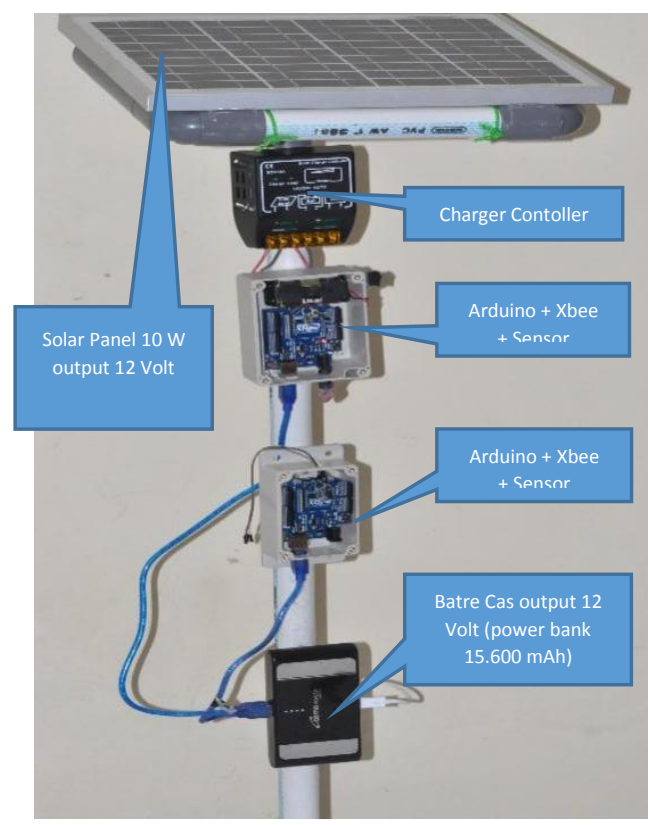

Gambar 3.1 Rangkaian sistem monitoring kualitas udara

3.2 Kombinasi alat sensor, arduino dan xbee

Penggabungan 3 (tiga) alat utama dalam medeteksi parameter suhu, gas dan debu harus sesuai dengan standar berdasarkan konektifitas arduino. Masing masing sensor secara umum memiliki 3 (tiga) bagian pin output yang berfungsi sebagai sumber tegangan (Vcc dan Gdn) dan output data (Vout). Secara detail akan dikaji sebagai berikut:

\subsubsection{Rangkaian sensor suhu}

Rangkaian antara Sensor Suhu, Arduino uno R3 dan Xbee S2 dapat dilihat pada Gambar 3.2

\section{HASIL DAN PEMBAHASAN}

\subsection{Rangkaian sistem monitoring kualitas udara}




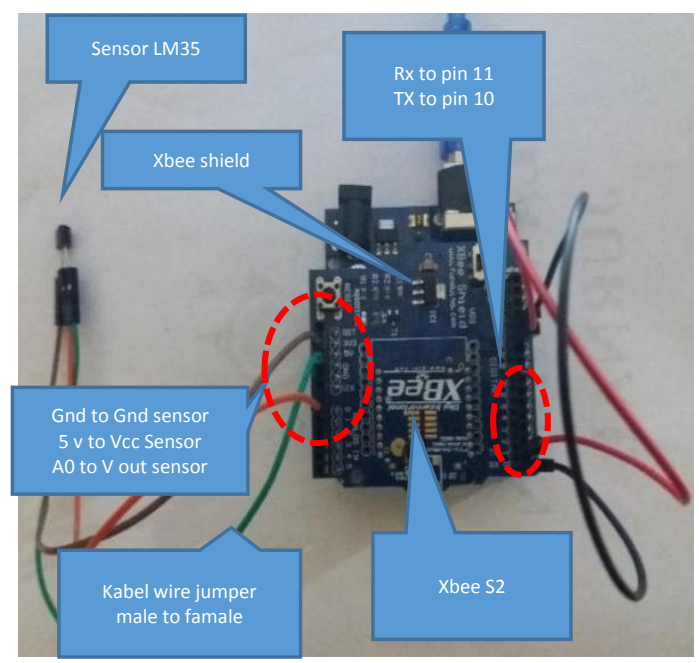

Gambar 3.2 Rangkaian LM35, Arduino Uni dan Xbee

\subsubsection{Rangkaian sensor gas CO}

Rangkaian antara Sensor MQ-9, Arduino uno R3 dan Xbee S2 dapat dilihat pada Gambar 3.3

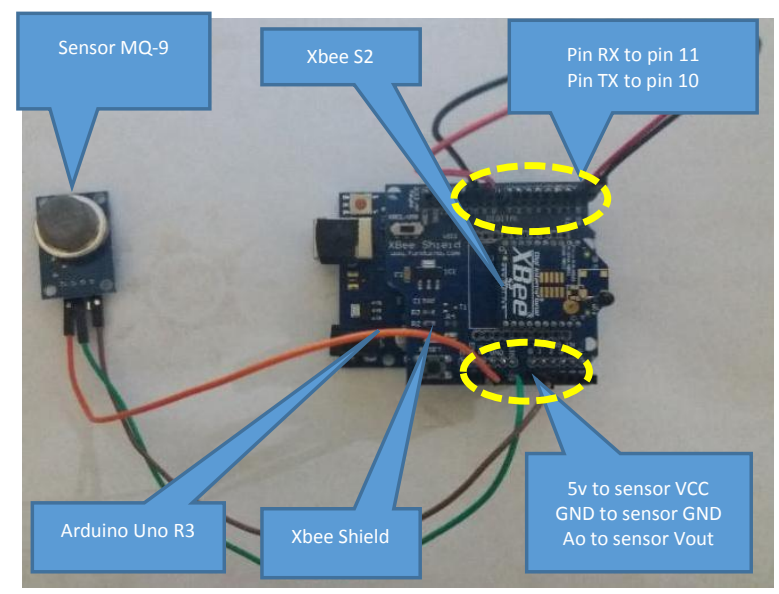

Gambar 3.3 Rangkaian MQ-9, arduino uno R3 dan xbee

\subsubsection{Rangkaian sensor gas LPG}

Rangkaian antara Sensor MQ-5, Arduino uno R3 dan Xbee S2 dapat dilihat pada Gambar 3.4

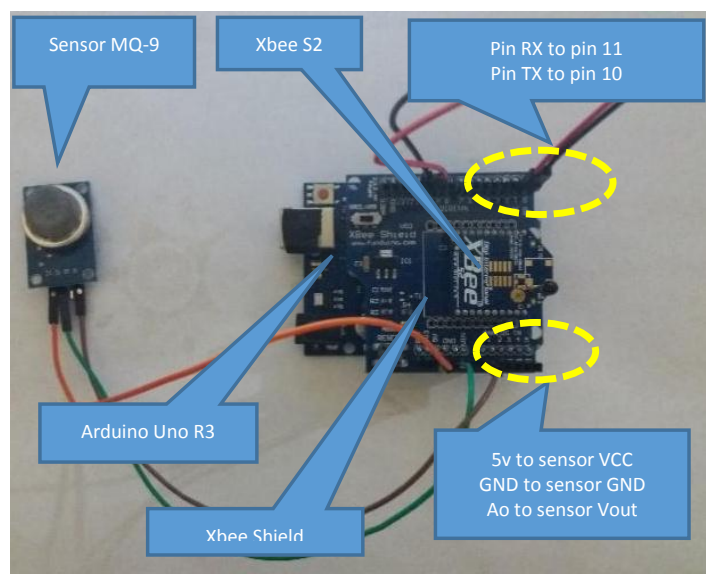

Gambar 3.4 Rangkaian MQ-5, Arduino Uno dan Xbee

\subsubsection{Rangkaian sensor debu}

Rangkaian antara Sensor Debu, Arduino uno R3 dan Xbee S2 dapat dilihat pada Gambar 3.5

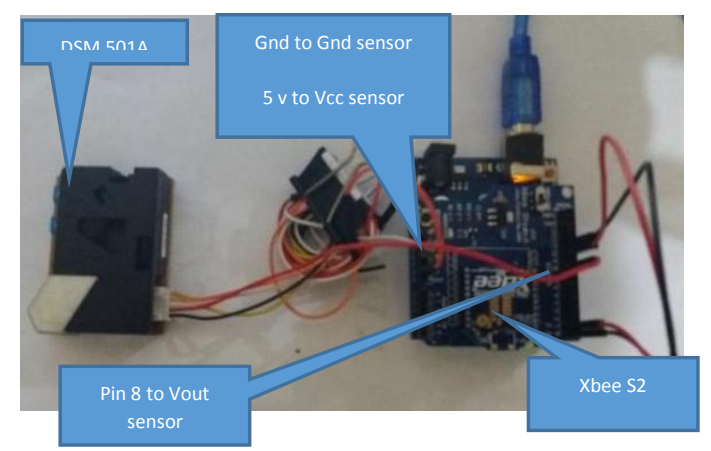

Gambar 3.5 Rangkaian DSM501A, arduino dan xbee $\mathrm{S} 2$

\subsection{Inisiasi program library sensor}

\subsubsection{Inisiasi program sensor suhu (LM 35)}

Inisiasi program library pada arduino IDE berjalan dengan sukses ditandai dengan tulisan pada bagian kiri bawah arduino IDE sofware "DONE UPLOADING" seperti pada Gambar 3.6 


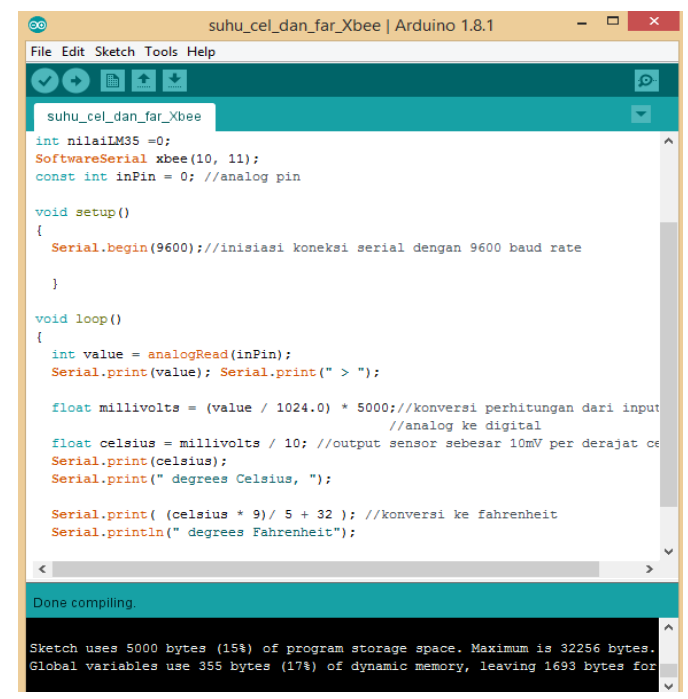

Gambar 3.6 Verifikasi library LM35 pada Arduino 1.8.1

Setelah dilakukan koneksi antara sensor 1M35 dan Arduino + Xbee, maka program inisiasi tersebut di upload seperti gambar 3.6. data serial yang dikirimkan antar node (pengirim dan Penerima) bisa dilihat pada serial Monitor Arduino Ide atau pada Program X-CTU. Seperti pada Gambar 3.7 dan 3.8.

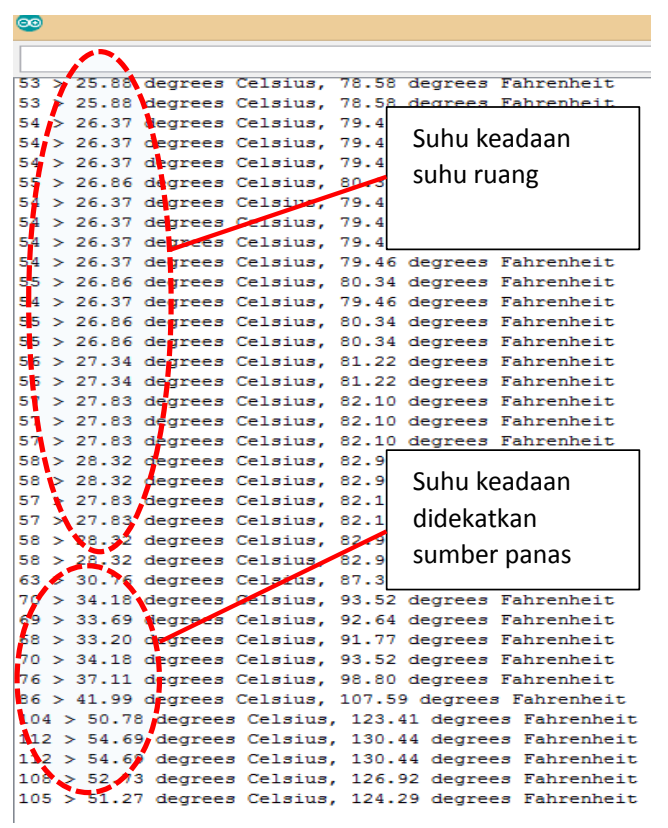

Gambar 3.7 Data serial monitor suhu sensor LM35

Ketika program dijalankan maka muncul data serial suhu satuan Celsius dan juga Farenheit yang telah di konvert dalam program arduino seperti pada Gambar 3.6. Respon sensor Suhu sangat baik ketika didekatkan dengan api dari korek gas. Data tersebut dapat dilihat pula pada grafik kenaikan suhu ketika ada respon terhadap panas seperti pada Gambar 3.8.

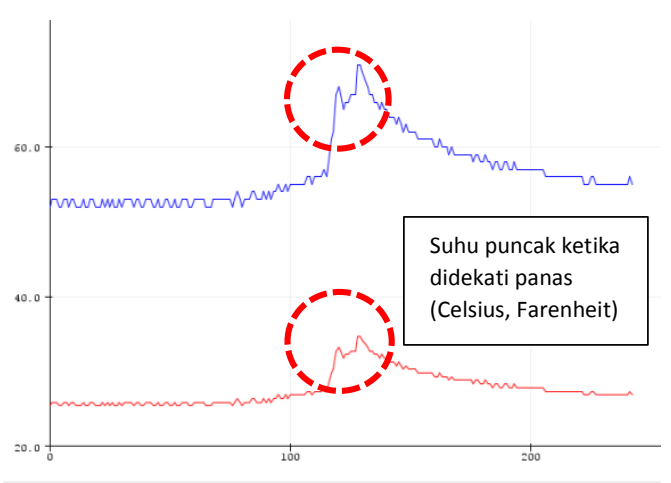

Gambar 3.8 Grafik peningkatan suhu sensor LM35 Ketika didekatkan panas

Grafik pada Gambar 3.8 menandakan respon sensor LM35 sangat baik dalam mendeteksi perubahan suhu secara sensitif. Kemampuan pembacaan suhu oleh sensor LM35 pada suhu dibawah standar ruang telah dicoba yakni ditempatkan delam es batu. Data tersebut dapat dilihat pada Gambar 3.9 dan 3.10

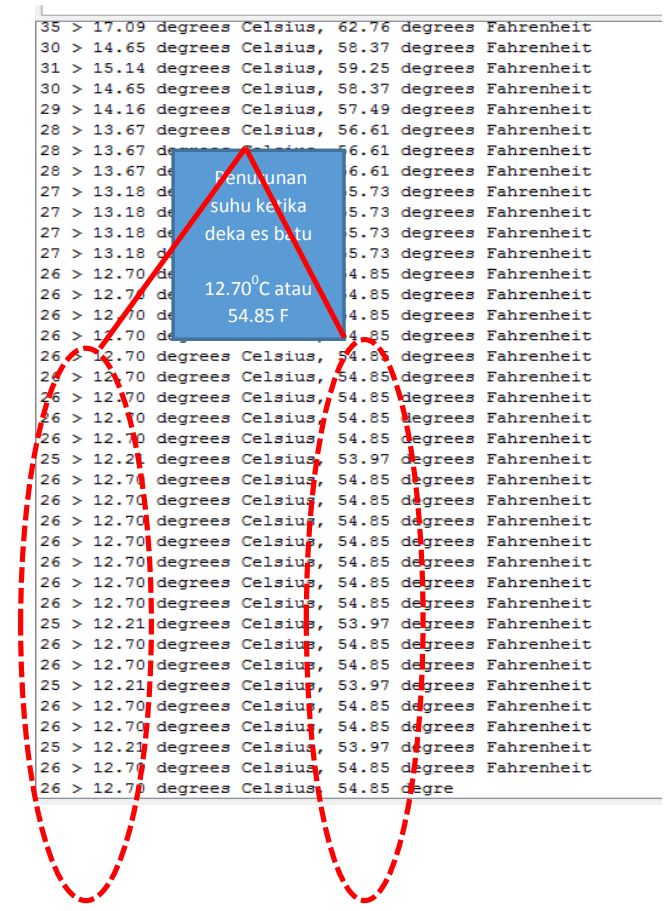


Gambar 3.9 Data penurunan suhu ketika ditempatkan dekat es batu

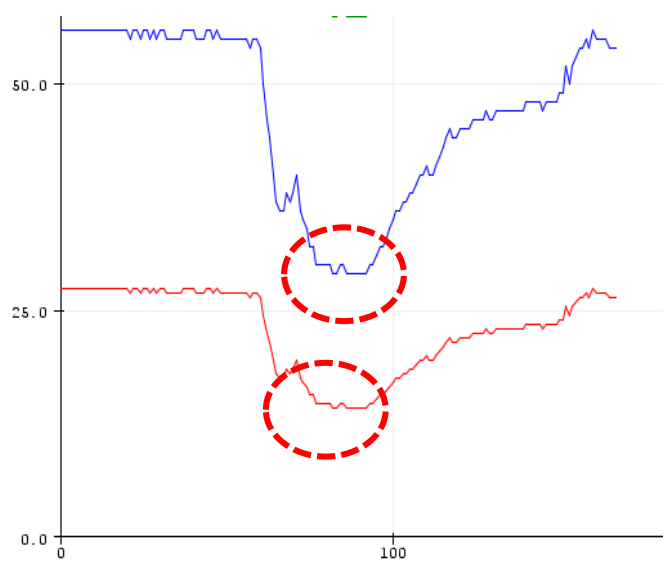

Gambar 3.10 Grafik data penurunan suhu penurunan suhu ketika dekat es batu

Berdasarkan data percobaan kondisi pembacaan sensor suhu ketika didekatkan dengan sumber panas dan dingin maka sangat sensitif dan akurat dalam mengirimkan data serial suhu. Ketika perbedaan suhu yang ekstrim diuji pada sensor ini maka kualitas pembacaannya masih dalam tahap penyesuaian dengan cepat tanpa mengalami kerusakan suhu. Hal tersebut dibandingkan dengan penggunaan termometer sebagai pembanding perubahan suhu.

\subsubsection{Inisiasi program sensor MQ-9 (carbon monoksida)}

Koneksi sensor MQ-9 pada arduino membutuhkan library khusus untuk mengirimkan data serial dan juga deteksi gas CO. Library pemrograman dimodifikasi dari library MQ-9 yang dikombinasikan dengan penambahan RXTX yang nantinya akan disatukan dengan Xbee S2. Inisiasi dan verifikasi library Sensor MQ-9 dapat dilihat pada Gambar 3.11 .

Sensor berbahan semikonduktor digunakan untuk mendeteksi keberadaan gas (Morin dan Santi, 2021). Berbagai penelitian material sensor berbasis semikonduktor telah dilakukan oleh peneliti sebelumnya, salah satunya dalam mendeteksi gas $\mathrm{H}_{2} \mathrm{~S}$ menggunakan $\mathrm{TiO}_{2}$ (Chinh dkk., 2019), ataupun bahan $\mathrm{TiO}_{2}$ doped $\mathrm{Fe}$ (Tong dkk., 2020).

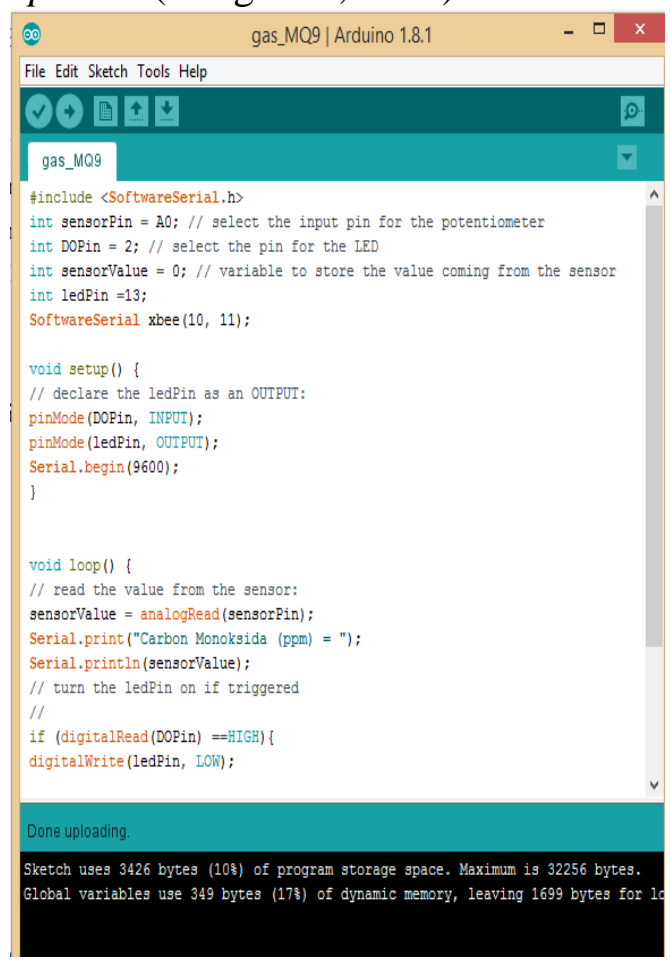

Gambar 3.11 Verifikasi library MQ-9 pada arduino 1.8.1 


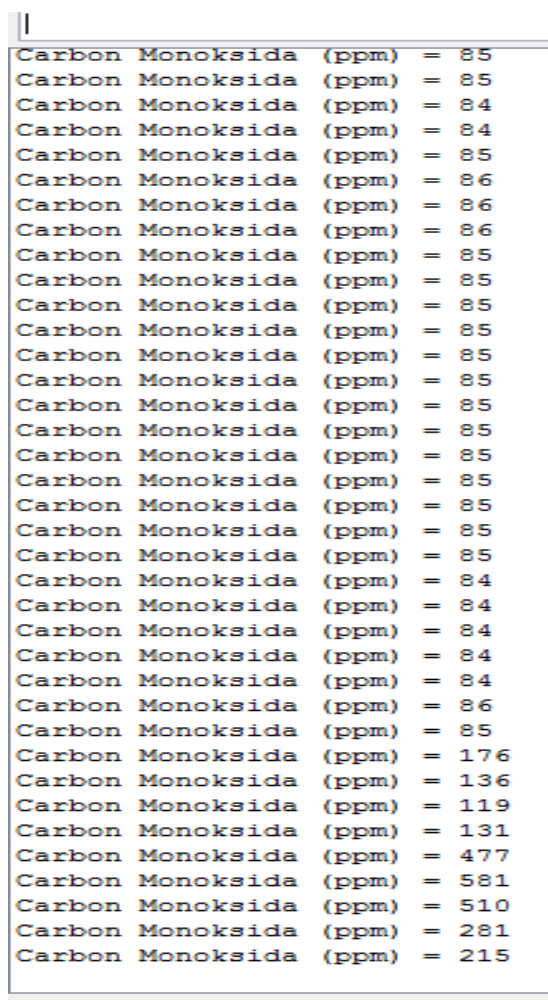

Gambar 3.12 Data serial monitor Sensor MQ-9 ketika kontak dengan gas CO

Sensor Gas Carbon Monoksida (CO) MQ-9, ketika dihubungkan dengan pin arduino uno R3 maka terjadi peningkatan suhu pada sensor MQ-9. Hal ini disebabkan bahan dasar pembentuk sensor ini terbuat dari bahan timah Oksida $\left(\mathrm{SnO}_{2}\right)$ sehingga dalam reaksi pengikatan dengan $\mathrm{CO}$ harus mengalami pembakaran atau dipanaskan sehingga oksigen $\left(\mathrm{O}_{2}\right)$ yang berada disekitar sensor ini akan ditarik ke dalam partikel $\mathrm{SnO}_{2}$ yang diperlukan pada proses pemanasannya. Ketika udara (oksigen) sekitar sensor menuju ke dalam partikel $\mathrm{SnO}_{2}$, maka bila ada molekul $\mathrm{CO}$ yang ada disekitarnya akan ikut bersama sama ke dalam partikel $\mathrm{SnO}_{2}$. Di dalam partikel penyusun sensor akan terjadi perpindahan elektron seperti terjadi pada reaksi:

$$
\mathrm{CO}+\mathrm{O}(\mathrm{ZnO}) \rightarrow \mathrm{CO}_{2}+(\mathrm{ZnO})
$$

Secara jelasnya digambarkan seperti pada Gambar 3.13

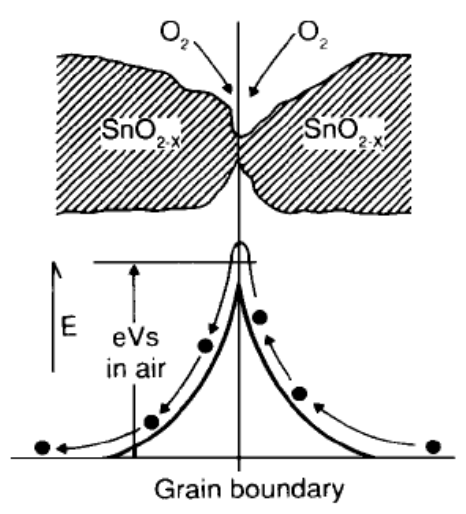

Gambar 3.13 Keadaan permukaan Sensor MQ-9 ketika menyerap gas

Secara rinci mengenai cara deteksi sensor MQ-9 di jelaskan sebagai berikut:

1. Reaksi tersebut terbentuk pada permukaan kristal sensor $\left(\mathrm{SnO}_{2}\right)$.

2. Tegangan permukan yang terbentuk akibat reaksi gas dan partikel $\mathrm{SnO}_{2}$ akan menghambat laju aliran elektron.

3. Di dalam sensor, arus elektrik mengalir melewati daerah sambungan dari kristal $\mathrm{SnO}_{2}$. Pada daerah sambungan, penyerapan oksigen berserta $\mathrm{CO}$ mencegah muatan untuk bergerak bebas

4. Jika konsentrasi gas menurun, proses deoksidasi akan terjadi, rapat permukaan dari muatan negatif oksigen akan berkurang dan mengakibatkan menurunnya ketinggian penghalang dari daerah sambungan misalnya terdapat gas CO.

5. Menurunnya ketinggian penghalang tersebut yang mengakibatkan terjadinya beda potensial dan menaikan sifat konduktivitas sehingga presentase gas yang terukur semakin besar. Grafik data peningkatan gas Carbon 
Monoksida (CO) dapat dilihat pada Gambar 4.9

Hambatan laju aliran elektron akan memberikan pengaruh pada proses perpindahan elektron dari keadaan dasar (pita konduksi) ke pita valensi sehingga akan berpengaruh pada resistansi dan nilai konduktivitas sensor (Morin dkk., 2020).

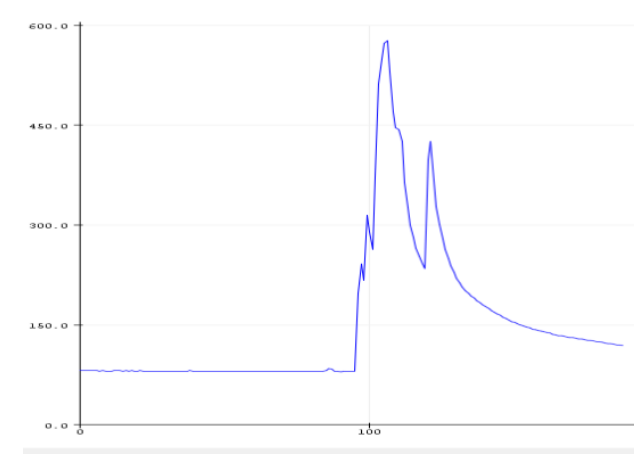

Gambar 3.14 Grafik data deteksi sensor MQ-9 ketika diberi gas CO

\subsubsection{Inisiasi program sensor MQ-5 (LPG)}

Library yang diprogram untuk pada arduino untuk menghubungkan Sensor MQ-5 dan Arduino Xbee S2 hampir menyerupai library pada sensor MQ-9. Library yang digunakan pada Arduino IDE ditunjukan pada Gambar 3.15 .

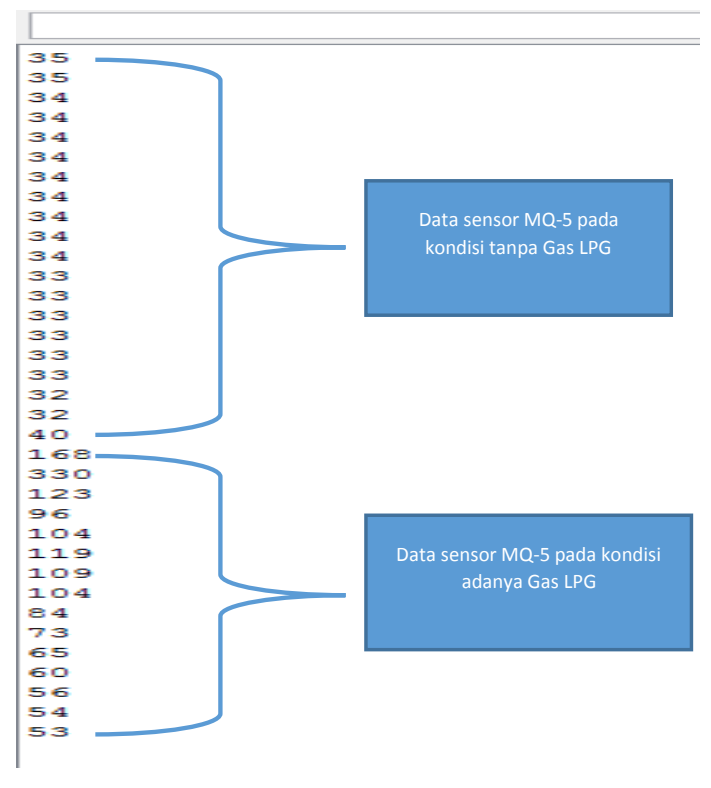

Gambar 3.15 Data serial monitor deteksi Sensor MQ-5 terhadap Gas LPG

Sensitifitas sensor MQ-5 ketika ada gas LPG maka pada serial monitor menampilkan gas elpiji secara cepat sesuai dengan delay waktu yang telah diatur pada library. Bentuk data serial dapat juga di gambarkan dalam bentuk grafik melalui serial plotter arduino IDE 1.8.1 seperti pada Gambar 3.16

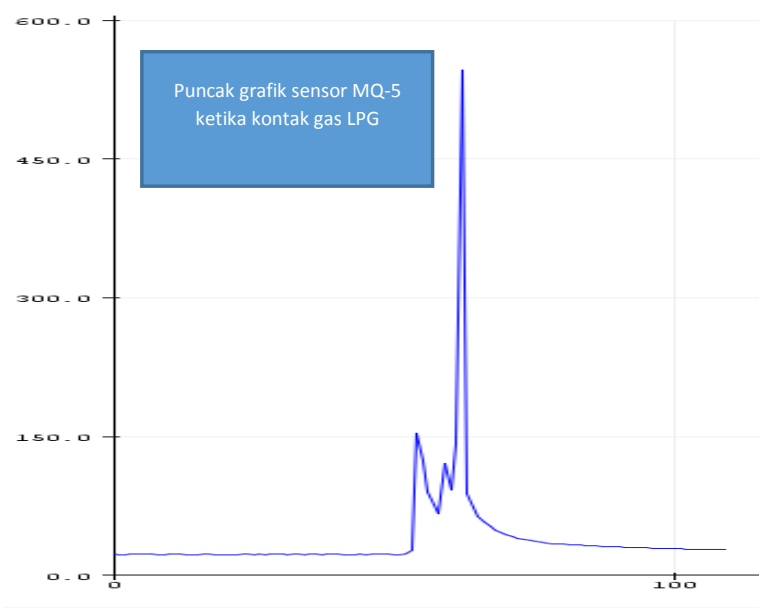

Gambar 3.16 Grafik data sensor MQ-5 ketika kontak gas LPG

\subsubsection{Inisiasi Program Sensor Debu DSM501A}

Library yang di program untuk pada arduino untuk menghubungkan 
Sensor Debu dan Arduino Xbee ditunjukan pada gambar 3.18.

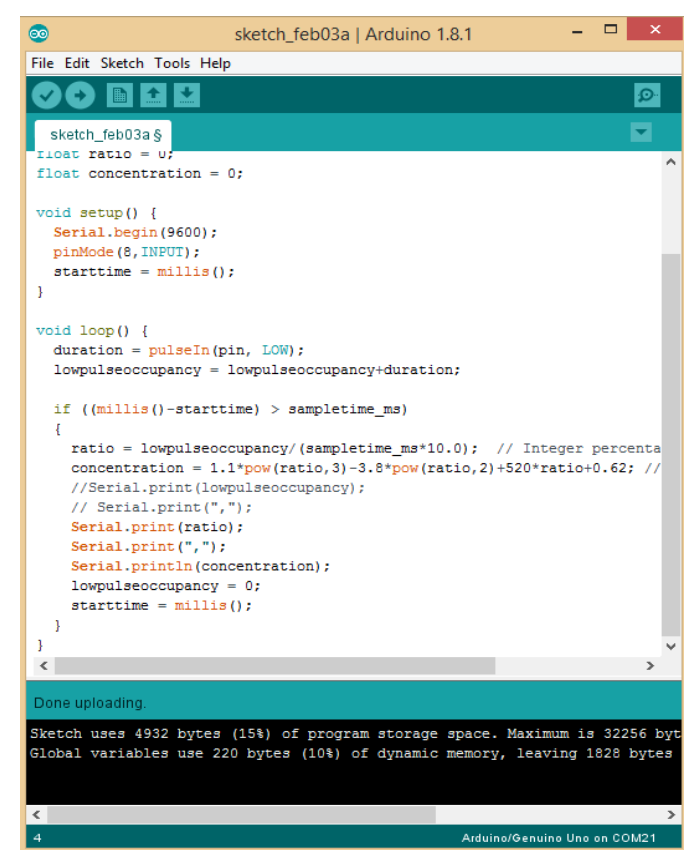

Gambar 3.18 Verifikasi Library DSM501A pada Arduino 1.8.1

Setelah dilakukan verifikasi kode dan upload kode library DSM501A pada arduino 1.8.1 maka secara otomatis detektor sensor debu mengirimkan data serial yang bisa dilihat pada serial monitor dan juga serial plotter (grafik) sofware Arduino IDE 1.8.1 seperti pada Gambar 3.19 dan 3.20

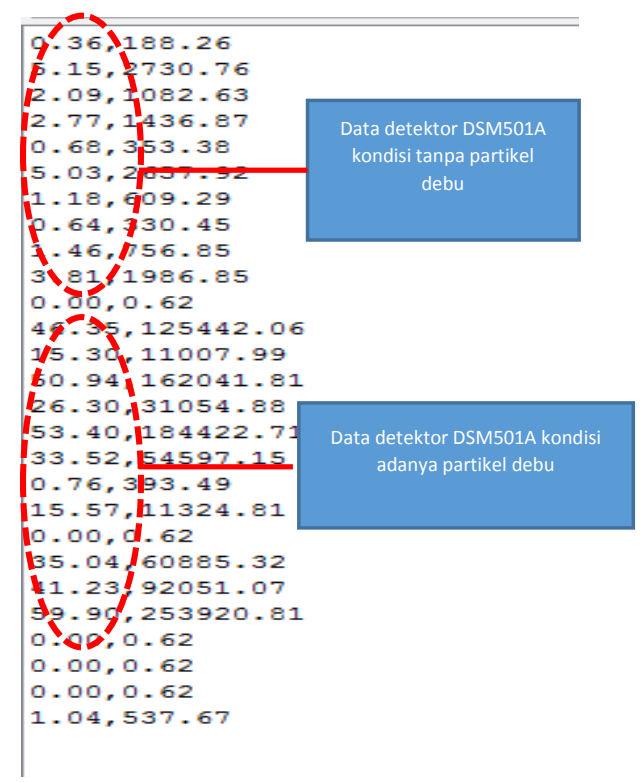

Gambar 3.19 Data serial DSM501A

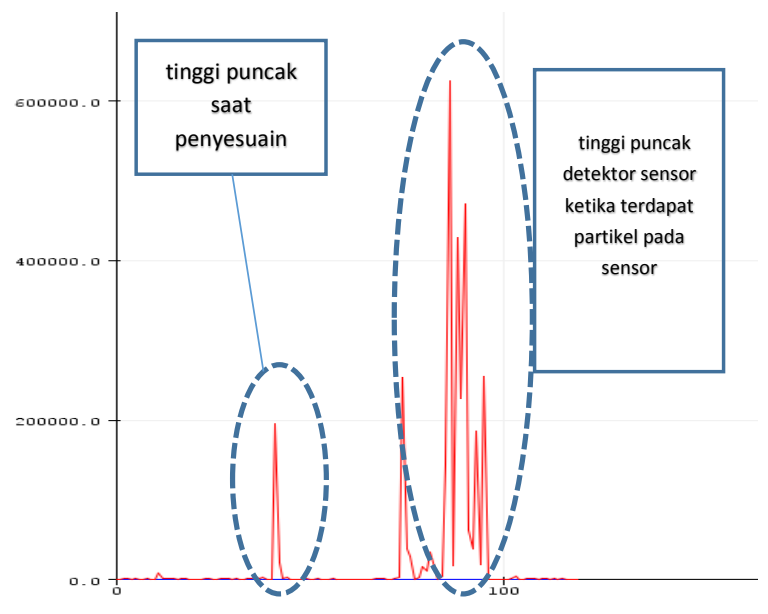

Gambar 3.20 Grafik data serial DSM501A

Pengujian sensor debu DSM501A yakni mengamati keluaran yang dihasilkan sensor tersebut. Perlu mengaktifkan LED internal dan menunggu 280 mikrodetik sebelum mengukur sinyal output dan durasi pulsa eksitasi seluruh harus 320 mikrodetik . Pada Gambar 3.20 terdapat 2 bagian puncak dimana pada puncak pertama terjadi pada saat sensor baru dihidupkan dan harus menunggu 320 mikrodetik untuk melakukan pembacaan data. Pada kelompok puncak kedua pembacaan sensor sudah stabil dan ketika terdapat partikel debu pada sensor maka terjadi kenaikan tinggi puncak seperti pada Gambar 3.20. setelah tidak adanya debu atau partikel maka grafiknya akan normal datar dengan menghasilkan nilai kadar debu yang rendah.

\section{KESIMPULAN}

Penelitian ini telah berhasil
merancang sistem pencemaran udara gas CO, LPG, Suhu dan Debu dengan protokol zigbee (Xbee S2). Penelitian yang telah dilakukan menghasilkan sebuah sistem yang secara realtime menampilkan data tingkat pencemaran udara gas karbon monoksida (CO) yang sangat berbahaya bagi 
kehidupan manusia serta adanya kebocoran gas LPG, suhu serta Debu. Sistem ini diharapkan membantu dalam pengontrolan wilayah. dari tingkat polusi udara gas CO, LPG, suhu dan debu. Pengontrolan ini dilakukan agar dapat dilakukan tindakan pencegahan pencemaran udara pada yang terdeteksi adanya peningkatan polutan tersebut.

\section{DAFTAR PUSTAKA}

Anonim, 2015. Parameter Pencemar Udara dan Dampaknya Terhadap Kesehatan. Departemen Kesehatan. http://www.depkes.go.id.

Chinh, N.D., Kim, C., and Kim, D., 2019. UV-Light-Activated $\quad \mathrm{H}_{2} \mathrm{~S} \quad$ Gas Sensing by a $\mathrm{TiO}_{2}$ Nanoparticulate Thin Film At Room Temperature, Journal of Alloys Compound, Vol.778:247-255.

Fardiaz, 2008. Polusi Air dan Udara, Kanisius. Yogyakarta.

Morin, J.V dan Santi, D, 2021. Pembuatan Sistem Vakum Otomatis Gas $\mathrm{H}_{2} \mathrm{~S}$ Berbahan $\mathrm{TiO}_{2}-\mathrm{Ni} / \mathrm{Al}_{2} \mathrm{O}_{3}$ Terkoneksi Arduino Uno Pada Laboratorium Kimia. Jurnal Natural. Vol.17, No.1:1-16.

Morin, J.V., Wahyuni, E.T., Suratman, A., and Ashari, A., 2020. Activity of Ni doped $\mathrm{TiO}_{2} /$ ceramic tube as a sensor of $\mathrm{CO}$ gas from motor vehicles, Rasayan Journal of Chemistry Vol. 13, No.2: 1225-1237.

Putu, A.E.P dan Suakanto, S., 2015. Wireless Sensor Network. Informatika Press. Bandung, Indonesia.

Tong, X., Shen, W., Zhang, X., Corriou, J.P., and Xi, H., 2020. Synthesis and Density Functional Theory Study of
Freestanding Fe-doped $\mathrm{TiO}_{2}$ Nanotube Array Film for $\mathrm{H}_{2} \mathrm{~S}$ Gas Sensing Properties at Low Temperature, Journal of Alloys Compound, Vol.832:155015. 